\title{
Reproductive losses to poisonous plants: Influence of management strategies
}

\author{
KIP E. PANTER, LYNN F. JAMES, DALE R. GARDNER, MICHAEL H. RALPHS, JAMES A. PFISTER, BRYAN L. \\ STEGELMEIER, AND STEPHEN T. LEE
}

Authors are Research Scientists, USDA, Agricultural Research Service, Poisonous Plant Research Laboratory, Logan, Utah, 84341.

\begin{abstract}
Poisonous plants that impair normal reproductive functions in livestock include Veratrum californicum Durand, lupines, ponderosa pine (Pinus ponderosa Dougl.), broom snakeweed (Gutierrezia sarothrae (Pursh) Britt. \& Rusby), locoweeds( Astragalus and Oxytropis spp.), selenium-containing forages, phytoestrogenic plants, endophyte-infected grasses and others. In this review we focus on lupines, locoweeds and ponderosa pine needles to demonstrate the broad and diverse effects that poisonous plants have on reproduction. Certain lupines (Lupinus spp.) contain quinolizidine and piperidine alkaloids that are fetotoxic and when grazed by pregnant cattle during specific stages of gestation induce skeletal birth defects and cleft palate, "crooked calf disease". Poison-hemlock (Conium maculatum) and some Nicotiana spp. contain similar alkaloids and induce identical birth defects in cattle, pigs, goats and sheep when ingested at certain stages of gestation. Locoweeds (species of the Astragalus and Oxytropis genera containing the indolizidine alkaloid swainsonine) interfere with most processes of reproduction when grazed for prolonged periods of time. Animals can recover normal reproductive function if withdrawn from locoweed grazing before severe poisoning occurs. While most animals may recover reproductive function, permanent neurological deficits may preclude normal reproductive behavior. Ponderosa and lodgepole pine needles (Pinus spp.) cause abortion in cattle when grazed during the last trimester of gestation. The specific chemical constituents responsible for the abortions belong to a class of compounds called labdane resin acids, including isocupressic acid (ICA), succinyl ICA, and acetyl ICA. Basic management recommendations to reduce reproductive losses to poisonous plants include: (1) keep good records; (2) know what poisonous plants grow on ranges and understand their effects; (3) develop a management plan to provide for alternate grazing in poisonous plantfree pastures during critical times; (4) provide for balanced nutrition, including protein, energy, minerals and vitamins; (5) maintain a good herd health program; (6) integrate an herbicide treatment program to reduce poisonous plant populations or to maintain clean pastures for alternate grazing; and, (7) manage the range for maximum forage production.
\end{abstract}

Key Words: Poisonous plants, lupine, locoweed, ponderosa pine, reproduction, management

Manuscript accepted 26 May 2001.

\section{Resumen}

Las plantas tóxicas que deterioran las funciones reproductivas normales del ganado incluyen a las siguientes especies: Veratrum californicum Durand, "Lupines", "Ponderosa pine" (Pinus ponderosa Dougl.), "Broom snakeweed" (Gutierrezia sarothrae (Pursh) Britt. \& Rusby), "Locoweeds"(Astragalus and Oxytropis spp.), forrajes que contienen selenio, plantas fitoestrogénicas, zacates infectados con hongos endófitos y otros. En esta revisión nos enfocamos en los "Lupinus", "Locoweeds"y hojas de "Ponderosa pine"para demostrar la amplitud y diversidad de efectos que las plantas tóxicas tienen en la reproducción. Ciertos "Lupines" (Lupinus spp.) contienen alcaloides quinolizidina y piperidina que son tóxicos para el feto, y cuando son apacentados por vacas preñadas durante etapas especificas de la gestación inducen a defectos esqueléticos al nacimiento y platosquisis, "enfermedad del becerro encorvado". "Poison-hemlock" (Conium maculatum) y algunas especies de Nicotiana spp. contienen alcaloides similares y cuando son ingeridos en ciertas etapas de la gestación inducen a defectos al nacimiento idénticos en bovinos, cerdos, caprinos y ovinos. Cuando los "Locoweeds" (especies de los géneros Astragalus and Oxytropis genera que contienen el alcaloide indolizidina swainsonina) son apacentados por largos periodos de tiempo interfieren con la mayoría de los procesos reproductivos. Los animales pueden recobrar sus funciones reproductivas normales si son retirados del "Locoweed" antes de que ocurra una intoxicación severa. Mientras que la mayoría de los animales puede recobrar su función reproductiva, déficit neurológicos permanentes pueden imposibilitar el comportamiento reproductivo normal. Las hojas de "Ponderosa" y "Lodgepole pine" (Pinus spp.) causan aborto en los bovinos cuando las apacientan durante el último trimestre de la gestación. Los constituyentes químicos específicos responsables de los abortos pertenecen a una clase de compuestos llamados ácidos resina labdano, incluyendo el acido isocupresico (ICA), ICA sucinil y ICA acetil. Las recomendaciones básicas de manejo para reducir las perdidas reproductivas por plantas tóxicas incluyen: (1) mantener buenos registros; (2) saber que plantas tóxicas crecen en los pastizales y entender sus efectos; (3) desarrollar un plan de manejo para proveer un apacentamiento alternativo en potreros libres de plantas tóxicas durante las épocas criticas; (4) suministrar una nutrición balanceada, incluyendo proteína, energía, minerales y vitaminas; (5) mantener un buen programa de salud del hato; (6) integrar un programa de tratamiento con herbicidas para reducir las poblaciones de plantas tóxicas o para mantener potreros limpios para apacentamiento alterno y (7) manejar el pastizal para obtener la máxima producción de forraje. 


\section{Lupinus spp.}

Lupinus spp. (lupines) contain quinolizidine and piperidine alkaloids that are toxic and teratogenic. Lupines have caused large losses to the sheep and cattle industries in the past and they continue to cause significant losses to the cattle industry in the western U.S. Recent calf losses from congenital birth defects have been reported in Oregon, Idaho, California, Nevada, Montana and Washington from 1992-1997 (personal communications). In $1992,56 \%$ of the calves from a single herd of cows either died or were destroyed because of skeletal malformations and/or cleft palate (Panter et al. 1997). In the spring of 1997 over 4000 calves ( $>35 \%$ of the calf crop) in Adams County, Washington were destroyed due to lupine-induced crooked calf disease (Dr. Clive Gay, unpublished data, 1997).

The clinical signs of acute poisoning begin with nervousness, depression, grinding of the teeth, frothing of the mouth, relaxation of the nictitating membrane of the eyes, frequent urination and defecation, and lethargy. These signs progress to muscular weakness and fasciculations, ataxia, collapse, sternal recumbency leading to lateral recumbency, respiratory failure, and death. Signs may appear as early as 1 hour after ingestion and progressively get worse over the course of 24-48 hours, even if further ingestion does not occur. Generally, if death does not occur within this time frame, the animal recovers completely if undisturbed (Panter et al. 1994).

More than 150 quinolizidine alkaloids have been structurally identified from genera of the Fabaceae family, including Lupinus, Laburnum, Cytisus, Thermopsis and Sophora (Kinghorn and Balandrin 1984). Eighteen western U.S. lupine species have been shown to contain the teratogen anagyrine (Fig. 1) with 14 of these containing teratogenic levels (Davis and Stout 1986). Two species, L. formosus E. Green and L. arbustus Lindley, contain teratogenic levels of the piperidine alkaloid ammodendrine (Fig., 1; Panter et al. 1998). Lupine alkaloids are produced by leaf chloroplasts and are translocated via the phloem and stored in epidermal cells and in seeds (Wink et al. 1995).

Piperidine and quinolizidine alkaloid content and profile vary between lupine species and in individual plants depending on environmental conditions, season of the year and stage of plant growth (Wink and

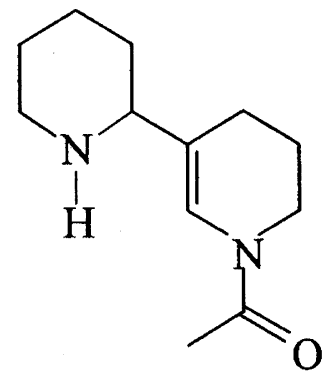

Ammodendrine

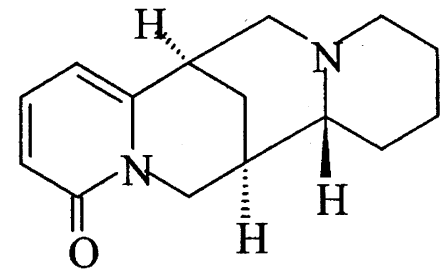

Anagyrine

Fig. 1. Two teratogenic alkaloids from Lupinus spp. that cause crooked calf disease and cleft palate. Ammodendrine is a piperidine alkaloid and anagyrine is a quinolizidine alkaloid.

Carey 1994). Alkaloid content (per gram of plant) may be highest during early growth stages, decreasing through the flower stage and concentrating in the maturing seeds. Seed pods are grazed by sheep and were responsible for large losses in the early 1900's (Chestnut and Wilcox 1901). The seed pod stage is a time when pregnant cattle may graze lupines resulting in deformed calf losses (Panter et al. 1997). Teratogenic effects depend on the amount of plant ingested and the concentration of teratogenic alkaloids in the plant. For example if a lupine species contained $2 \%$ total alkaloid and $25 \%$ of that was anagyrine, research suggests that the cow would need to consume between 2 and 4 gm dry weight of plant material per $\mathrm{kg}$ body weight per day over a period of many days (at least 8-10) to cause birth defects (Gardner and Panter 1993). Seed pods usually contain higher levels of the toxins and are often more palatable than other plant parts.

Influences of site and elevation on alkaloid content have been described (Carey and Wink 1994). Total alkaloid content decreases as elevation increases and was shown to be 6 times higher in plants at $2,700 \mathrm{~m}$ vs plants collected at $3,500 \mathrm{~m}$. This phenomenon persisted even when seedlings from the highest and lowest elevations were grown under identical green house conditions, suggesting evolutionary genetic differences. For many lupines, the time and degree of seeding varies from year to year. Many lupines possess high nutrient qualities and would be considered good range forage if the toxic/teratogenic alkaloids were not present. In some circumstances, lupine is considered good range forage and may be grazed relatively safely. Most deaths have occurred under conditions in which animals consume large amounts of pods or toxic plants in a brief period. This has been reported in sheep, but reports of death losses in cattle are rare. Most losses happen when livestock are driven through an area of heavy lupine growth, unloaded into such an area, trailed through an area where the grass is covered by snow but the lupine is not, or when animals are forced to eat the plants due to over-grazing. Recently, 10 yearling stocker calves died after grazing Lupinus argenteus containing predominantly the piperidine alkaloids ammodendrine and $\mathrm{N}$ methyl ammodendrine (Fig. 1; Panter et al. 2001). Poisonings generally occur in the late summer and fall when seed pods are present and lupine remains green after other forage has matured or dried.

\section{Teratogenicity}

Those lupine species containing the teratogenic alkaloid anagyrine present significant risks to cattle producers when pregnant cows are allowed to graze on infested pastures during susceptible stages of gestation. The defects are characterized as one or more of the following: arthrogryposis (contracture and malalignment defects of the limbs), scoliosis (spinal column twisting), torticollis (deformed neck), kyphosis (spinal depression) and cleft palate (Panter et al. 1990). While the bone and joint development appears to be normal, the defects are believed to be contracture-type defects resulting from abnormal tendon, muscle and ligament tension induced by a lack of fetal movement during susceptible periods of gestation (Panter et al. 1990).

\section{Susceptible Periods of Gestation}

The susceptible periods of gestation have been defined in cattle. The severity and type of the malformations also depend on the alkaloid dosage ingested, the stage of pregnancy when the plants are eaten, and the length of time ingestion takes 
place. The most critical gestational period for exposure in cattle is 40-70 days, with susceptible periods extending to 100 days (Shupe et al. 1968a, 1968b; Panter et al. 1997). The cleft palate-induction period in cattle was recently defined within gestation days 40-50 (Panter et al. 1998).

\section{Livestock Species Differences}

The syndrome known as crooked calf disease associated with lupine ingestion was first reported in the late 1950's and included various skeletal contracture-type birth defects and occasionally cleft palate (Palotay 1959, Wagnon 1960, Binns and James 1961, Shupe et al. 1967a, 1967b). Epidemiologic evidence and chemical comparison of teratogenic and non-teratogenic lupines has determined that the quinolizidine alkaloid anagyrine is the teratogen (Keeler 1973, 1976). A second teratogen, ammodendrine, was found in Lupinus formosus and induced similar types of skeletal birth defects (Keeler and Panter 1989). Further research determined that the anagyrine-containing lupines only caused birth defects in cattle and did not affect sheep or goats. No breed predilection or genetic susceptibility to the lupineinduced condition has been determined in cattle. The piperidine-containing lupine $L$. formosus (i.e., no anagyrine) caused birth defects in experimentally treated cattle and goats (Keeler and Panter 1989, Panter et al. 1994). Other piperidine alkaloids and piperidine-containing plants also cause contracture-type birth defects and cleft palate in cattle, sheep, pigs and goats (Panter et al. 1999a, 2000). These studies led to speculation about possible metabolism or absorption differences between cattle and small ruminants. Keeler and Panter (1989) hypothesized that cattle might metabolize the quinolizidine alkaloid anagyrine to a complex piperidine, meeting the structural characteristics determined for the simple teratogenic piperidine alkaloids in poison-hemlock (Keeler and Balls 1978). This was supported by feeding trials with other piperidine alkaloid-containing plants, extracts, and pure compounds. Even though comparative studies supported the hypothesis that the cow may convert the quinolizidine alkaloid anagyrine to a complex piperidine by ruminal metabolism, recent evidence reporting the absorption and elimination patterns of many of the quinolizidine alkaloids, including anagyrine, in cattle, sheep, and goats does not support this theory (Gardner and Panter 1993).

\section{Mechanism of Action}

The proposed mechanism of action for lupine-induced malformations and cleft palate in cattle has been elucidated using a goat model. Panter et al. (1990) hypothesized that the mechanism involves a chemically-induced reduction in fetal movement much as one would expect with a sedative, neuromuscular blocking agent, or anesthetic. This proposed mechanism of action was supported by experiments using radio ultrasound where a direct relationship was recorded between reduced fetal activity and severity of contracturetype skeletal defects and cleft palate in sheep and goats. Further research suggests that this inhibition of fetal movement must be over a protracted period of time during specific stages of gestation.

Ultrasonographic studies (Panter et al. 1991) demonstrated that strong fetal movement occurs in the untreated goat at about day 35 of gestation, with extensiontype movements of the fetal head and neck. Under the influence of certain teratogenic alkaloids through days 35-41 of gestation, fetuses remained tightly flexed with their chin on the sternum and there were no extension-type movements. Subsequently, the newborn goats from affected does had cleft palates but no other birth defects. Panter and Keeler (1992) suggested that these cleft palates were caused by an alkaloid-induced mechanical interference by the tongue between palate shelves during programmed palate closure times (day 38 in goats; between days 40 to 50 in cows).

In addition to lupines, poison-hemlock and certain Nicotiana spp. contain piperidine and quinolizidine alkaloids that are structurally similar to those expected to be toxic and teratogenic. Other potentially teratogenic genera include: Genista, Prosopis, Lobelia, Cytisus, Sophora, Pinus, Punica, Duboisia, Sedum, Withania, Carica, Hydrangea, Dichroa, Cassia, Ammondendron, Liparia, Colidium (Keeler and Crowe 1985). Many plant species or varieties from these genera may be included in animal and human diets, but toxicity and teratogenicity are dependent on dose, rate of ingestion, and alkaloid level and composition in the plant.

\section{Prevention and Treatment}

Prevention of poisoning and birth defects induced by Lupinus can be accomplished by using a combination of management techniques including: 1) identifi- cation of lupine species and alkaloid profiles; 2) coordinating grazing times to avoid the most toxic stages of plant growth such as early growth and the seed pod stage; 3 ) altering breeding times, either advancing, delaying or changing from spring to fall calving; 4) reducing lupine plant density through herbicide treatment; 5) managing grazing to maximize grass coverage; 6) intermittent grazing, allowing short duration grazing of lupine pastures with frequent rotation when cows are first observed grazing lupine plants; and 7) diversify livestock programs to include stockers or sheep grazing on heavily infested pastures. These recommendations have been available for many years and some have been used successfully to reduce losses from lupine (Keeler et al. 1977). Further discussion of these recommendations follow:

1) Identification of toxic lupine species is a key element in managing livestock to avoid losses. Keeler (1976) identified anagyrine as the teratogenic quinolizidine alkaloid in lupine species. Those species with a known history of teratogenic risk include L. sericeus Pursh., L. caudatus Kellogg, L. leucophyllus Douglas ex. Hooker, L. latifolius J. Agardh, L. sulphureus, Douglas ex. Lindley, L. polyphyllus Lindley, L. argenteus Pursh. L. formosus E. Greene, L. arbustus Lindley. Wink et al. 1995, identified 14 lupine species containing teratogenic levels of anagyrine. Therefore, identification of lupine species found in pastures and subsequent quantitative analysis to identify chemical composition will determine risk.

2) Chemical analysis of lupines indicate the alkaloid concentration in the vegetative material. Generally, alkaloids are highest in the early growth and seed pod stage (Keeler 1973). The alkaloids are translocated and concentrated in the seeds (Wink and Carey 1994). Thus, avoiding grazing during the early growth stage or seed pod stage of plant growth will minimize risk. This is especially true for the seed pod stage as cattle and sheep are reported to graze seed pods (Chestnut and Wilcox 1901, Keeler et al. 1977, Panter et al. 1997). Proximate analysis of seed pods demonstrated that lupine seeds are a good source of protein (Panter et al. 2001). Cattle and sheep are less likely to graze early growth lupines if there is adequate good quality grass.

3) Research has determined that the susceptible period of gestation for induction of "crooked calf disease" is 40 to 70 days 
extending to day 100 in extreme cases (Shupe et al. 1968b; Panter et al. 1997). Therefore, preventing exposure of pregnant cattle to lupines, especially, in the seed pod stage, during the susceptible stages of pregnancy will prevent losses. This can be accomplished by changing breeding schedules the most extreme of which would be changing from a spring calving program to a fall calving program. This has been used in some cases in the northwest where lupine-induced crooked calf disease has been a serious problem.

4) Lupines often grow in localized areas within a pasture. Therefore, herbicide control may be accomplished and economical by spraying limited areas of land where lupine populations are most dense. This method of treatment would reduce numbers of lupine plants and may increase forage production. Control of poisonous plants will allow greater flexibility in management by increasing length of time of grazing, pasture productivity and increase stocking rate. All of these parameters factor into the economic benefit of herbicide use. Effective herbicides include 2,4-D with or without dicamba at 1.2:0.6 $\mathrm{kg} \mathrm{ai} / \mathrm{ha}$ (combination) or $2.2 \mathrm{~kg}$ ai/ha (2,4-D alone), or triclopyr at $0.6-1.68 \mathrm{~kg}$ ai/ha. Bud to early bloom is the most effective plant growth stage for control (Ralphs et al. 1991). Once control of lupine has been accomplished, management for maximum forage production will help prevent further infestations.

5) Grazing programs and pasture management to maximize grass production is an important method in preventing lupine and other poisonous plant problems. This is especially true during drought years as lupine is a deep rooted legume and often increases in density after drought years.

6) Research has determined that the mechanism of action of lupine induced crooked calf disease is an alkaloid-induced reduction in fetal movement over a protracted period during susceptible stages of gestation. By interrupting this mechanism and removing the pregnant animal from the lupine source for brief periods (3-5 days), normal fetal movement would be restored and malformations could be avoided. Recent research would suggest this intermittent period to be 5-7 days and would depend on close observation of cattle to determine when they start grazing lupine plants. This would require intense management and a relatively clean pasture where cattle could be moved during this intermittent period.

7) Lupine poisoning in sheep was extensive in the early 1900's and large losses were reported, however most of these losses occurred when lupine hay containing many seed pods were fed or sheep were grazed on concentrated patches of lupine (Chestnut and Wilcox 1901). Sheep are more resistant to the toxic effects of lupine than are cattle and malformations are infrequent and not associated with anagyrine. Therefore, sheep could be used as an alternate livestock specie for lupine grazing or potentially sheep could be grazed ahead of cattle to reduce lupine seed pod availability. Also, few reports of overt toxicoses in cattle are reported. Clearly, the malformation issue is the largest economic risk from lupine to cattle producers. Using stockers could potentially utilize lupine infested ranges more efficiently thus avoiding the "crooked calf disease" issue. A combination of grazing stockers on lupine infested pastures and cow-calf pairs on the cleaner pastures could potentially enhance utilization of ranges. By using a combination of these management tools, most losses can be avoided and ranges utilized more efficiently.

When malformed calves are born, decisions must be made as to the disposition of these calves. Severity of malformations often determine the outcome at the time of birth. Calves with severe arthrogryposis, scoliosis, cleft palate etc. should be euthanized soon after birth as they will not be economical to keep and often cannot survive more than a few days. Calves with contractures of the front legs in which they can lock the knee joint will usually straighten up and as long as they can travel with their mother and nurse, will grow relatively normally and can be considered economical to keep.

\section{Locoweeds}

Locoweeds, species of Oxytropis and Astragalus that contain the $\alpha$-mannosidase inhibitor swainsonine (Fig. 2), reduce reproductive performance in multiple ways when livestock graze these plants for extended periods of time. Most aspects of reproduction are affected, including mating behavior and libido in males, behavioral estrus and conception in females, fetal growth and development and neonatal/maternal behavior. While extensive research has characterized and described histological changes in most organ sys-

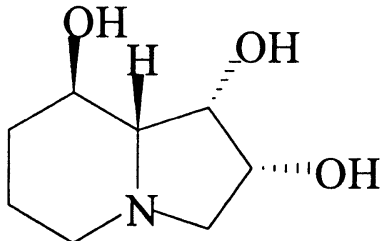

\section{Swainsonine}

Fig. 2. Swainsonine, the indolizidine alkaloid toxin in locoweeds.

tems (Van Kampen and James 1970), detailed studies describing the magnitude of physiological problems and mechanisms of action are very limited and therefore further research is needed.

Once animals begin to graze locoweed, measurable increases in serum swainsonine cause an immediate decline in serum $\alpha$-mannosidase activity. Alpha-mannosidase is an important enzyme in cellular glycoprotein processing, and many reproductive hormones and receptors are glycoproteins. While these measurable changes are diagnostic during the grazing of locoweeds, the rapid clearance of swainsonine from serum $\left(\mathrm{t}_{1 / 2} \approx .20 \mathrm{hrs}\right)$ and accompanying recovery of $\alpha$-mannosidase activity $\left(\mathrm{t}_{1 / 2} \approx .65\right.$ hours) limits serum analysis of these parameters as a reliable test for locoweed exposure if animals have not ingested locoweed in the previous several days (Stegelmeier et al. 1995a, 1995b). Currently, diagnosis of locoweed poisoning relies on history of locoweed ingestion, behavioral changes, loss of condition and, in terminal cases, histological evidence of neurovisceral vacuolation. Histological lesions induced by locoweed ingestion and experimental feeding of purified swainsonine (James et al. 1991, Stegelmeier et al. 1995a, 1995b) have been compared and found to be the same. Lesions appear to develop in a thresholdlike fashion since the severity of lesions does not increase at higher locoweed doses (Stegelmeier et al. 1995a, 1995b). Animal tissues that accumulate high swainsonine concentrations (such as liver and kidney) develop lesions more rapidly, and at lower dosages of locoweed, than do other organ systems (such as blood and muscle). Even though $\alpha$-mannosidase activity recovers quickly, tissue repair and return to normal organ function occur more slowly (Stegelmeier et al. 1999). We would expect this to be true also for the reproductive system. 


\section{Effects on Female Reproduction}

Locoweeds affect almost every aspect of reproduction in the female, such as estrus behavior, estrous cycle length, ovarian function, conception, embryonic and fetal viability, and maternal/infant bonding (Pfister et al. 1993, Panter et al. 1999b, 1999c).

Locoweed fed to cattle and sheep at various times and dosages temporarily altered ovarian function, increased estrous cycle length, altered breeding behavior and reduced conception rates. Recent feeding trials with locoweeds (A. mollissimus, Torr., A. lentiginosus Douglas and $O$. sericea Nutt. ex. Torr. and Gray) in cycling ewes demonstrated that after 20 days of locoweed feeding at $10-15 \%$ of their diet, estrus was delayed and shortened, conception rates decreased and the number of viable embryos collected from superovulated ewes was reduced (Panter, K. E., unpublished data).

While only a few abnormal morulastage embryos were collected from ewes fed locoweed for 30 days (Panter, K.E., unpublished data), recent in vitro data demonstrated that swainsonine added to culture media at different concentrations (up to $6.4 \mu \mathrm{g} / \mathrm{ml}$ ) did not directly interfere with oocyte maturation (IVM), in vitro fertilization (IVF), or embryo growth and development (Wang et al. 1999). Pregnancy rates were not different from controls when swainsonine-cultured bovine embryos were transferred to recipient cows. This research suggests that the effects of locoweed on early embryo viability and development may not be from primary effects of swainsonine but rather secondary pathways, and result from the effects of locoweed (swainsonine) on maternal aspects of reproduction such as the pituitary/hypothalamic axis where glycoprotein gonadotropins are produced and released.

Mature cycling cows fed Oxytropis sericea at $20 \%$ of their diet for 30 days showed moderate signs of toxicity. The estrous cycle length increased during locoweed feeding and conception was decreased (Panter et al. 1999c). After feeding stopped, normal estrous cycle length returned relatively soon and cows bred normally, although conception was delayed in some cows (repeat breeders) for up to 3 estrous cycles. In another study cycling heifers fed $O$. sericea equivalent to 3 dosages of swainsonine $(0.25,0.75$, and $2.25 \mathrm{mg} / \mathrm{kg} /$ day) showed ovarian dysfunction in a dose-dependent pattern (Panter, unpublished data). Heifers receiv- ing the highest dose for 45 days had enlarged ovaries by day 20 of locoweed feeding. Observation of these ovaries by ultrasound suggested that both the luteal phase (observation of corpus luteum) and follicular phase (observation of a follicular cyst) were prolonged and persisted throughout the feeding period (Panter, unpublished data). Within 30 days after locoweed feeding had stopped, ovaries appeared normal via ultrasound, and 15 days later when heifers were necropsied the ovaries were similar in appearance to those of controls.

While gross and microscopic lesions in the dam may resolve quickly after locoweed ingestion ceases, effects on the fetus may be prolonged and severe enough to result in abortion, small and weak offspring at birth, or reduced maternal/infant bonding and impaired nursing ability of the neonate (Panter et al. 1987, Pfister et al. 1993). Locoweed ingestion by pregnant ewes during gestation days 100-130 disrupted normal maternal infant bonding compared to control ewe-lamb pairs (Pfister et al. 1993). Lambs from mothers ingesting locoweed failed to suckle within 2 hours after birth, were slower to stand, and were less vigorous than control lambs. Thus, maternal ingestion of locoweed disrupted the learning ability of their neonatal lambs. Swainsonine is also excreted in the milk and can result in further intoxication of nursing offspring or exacerbate intoxication when offspring begin to graze locoweeds and continue to nurse their locoweed-grazing mothers (James and Hartley 1977, Ralphs et al. 1994). In northern Colorado, Knight and Greathouse (1996) reported that locoweed-intoxicated weanling calves required 64 more days in the feedlot than normal calves to reach slaughter weight and condition. This same group of calves also demonstrated immunological deficiencies and the incidence of respiratory and other diseases and mortality was higher than normal.

\section{Effects on Male Reproduction}

The effects of locoweed ingestion are also detrimental to male reproductive function. Panter et al. (1989) reported transient degenerative changes in the seminiferous, epididymal, and vas deferens epithelia after feeding locoweed to yearling rams for 70 days. Clinically, there were changes in behavior, reduced libido, and loss of body condition. There were no gross changes in testicular circumference or tissue appearance but, histologically, there was foamy, cytoplasmic vacuolation in the epithelium of the seminiferous tubules, epididymis and vas deferens and reduced spermatozoa production. Semen contained significantly more abnormal spermatozoa, including retained perinuclear cytoplasmic droplets, detached tails, bent tails and marked decreases in motility. These changes in spermatozoa were transient and by 70 days after locoweed feeding stopped, the rams appeared clinically normal. More recent studies using 2-year-old rams further confirmed these results. Long-term neurological deficits did not reverse, and in some rams intensified, which precluded using these animals for breeding. After withholding locoweed for 60 days, semen parameters appeared normal, but the neurological deficits including proprioceptive defects, tremors and aberrant behavior did not reverse but rather intensified. Over half $(5 / 7)$ of the treated rams lost weight and became emaciated. All treated rams were euthanized and necropsied (Wang et al. 1998, Panter, unpublished data); histological evaluation of tissues has not been completed.

Ortiz et al. (1997) reported several delayed effects after feeding Oxytropis sericea to breeding age ram lambs for 35 days. Subsequently, 35 days after locoweed feeding had stopped, they found reduced sperm motility and decreased scrotal circumference in all treated rams. There was also reduced testosterone responses to a gonadotrophin releasing hormone $(\mathrm{GnRH})$ challenge, suggesting that locoweed affected testicular function. The delayed effect was expected as the normal cycle of spermatogenesis in sheep is about 60 to 70 days. Panter et al. (1989) demonstrated that increased spermatozoa abnormalities peaked after continuous feeding of locoweed for 70 days.

\section{Prevention and Recommendations}

While research and field observations have demonstrated that locoweed affects almost every aspect of reproduction in livestock, several questions still need to be answered. How much locoweed can livestock eat, and over what time period, before reproduction declines? What functions are affected first? How long does it take for reproductive function to return to normal once locoweed ingestion stops? When are reproductive effects irreversible? What are the modes of action? 
When does neurological dysfunction preclude use of animals for reproduction? Many of these questions are being studied at this time which will provide information that will aid management decisions to improve reproductive performance and allow better utilization of locoweed-infested ranges.

Recent research demonstrated that effects of locoweed on livestock are almost immediate. After one day of experimental feeding of locoweed to cows and sheep, blood serum $\alpha$-mannosidase activity dropped significantly concomitant to an almost immediate rise in serum swainsonine (Stegelmeier et al. 1995b). Therefore, there is no $100 \%$ safe period of grazing locoweed. However, this is not to say that a certain amount of locoweed grazing cannot be tolerated by animals, but decisions must be made based on the livestock programs and sound research-based decisions as to how much locoweed can be grazed before production decreases.

At present, it is recommended that breeding males should not be exposed to locoweeds within 90 days of the breeding season; pregnant animals should be removed from locoweed infested pastures as soon as locoweed ingestion begins; loco-free pastures should be maintained with herbicides as a place to move animals when they start to graze locoweeds; and, breeding females should not be allowed to graze locoweeds for extended periods of time generally more than 2-3 weeks.

\section{Ponderosa Pine and Related Species}

Ponderosa pine needles (PN) induce abortion in cattle when eaten during the last trimester of gestation (James et al. 1989, 1994). A labdane resin acid, isocupressic acid (ICA), was identified as the abortifacient compound (Gardner et al. 1994; Fig. 3). Further studies identified 2 other labdane resin acids, succinyl ICA and acetyl ICA, both of which are hydrolyzed in the rumen to ICA (Gardner et al. 1996, 1997). Rumen and liver metabolites have recently been identified but abortifacient activity of the major metabolites have yet to be characterized (Gardner et al. 1999). Pine needles were not abortifacient in goats and sheep nor was ICA abortifacient in goats when administered orally or iv (Gardner, D. R., unpublished data).

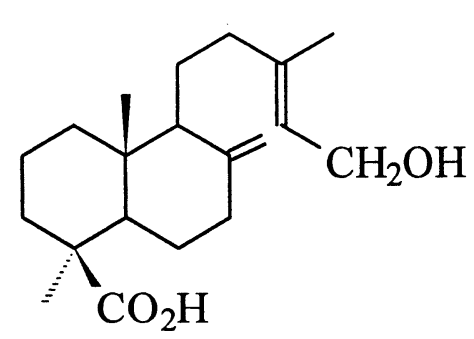

Isocupressic acid

gastroenteritis (Stegelmeier et al. 1996). While abietane-type resin acids may contribute to the occasional toxicoses reported in the field, they do not contribute to the abortions. Most cow losses in the field are associated with difficult parturition or post abortion toxemia due to retained fetal membranes.

Cattle readily graze ponderosa pine needles, especially during the winter months in the western U.S.

Fig. 3. Isocupressic acid, the labdane resin acid in Pine needle consumption increases Ponderosa pine needles responsible for abortions in cattle.

Twenty-three other tree and shrub species found throughout the western and southern states were analyzed for ICA (Gardner et al. 1998, Gardner and James, 1999). Significant levels ( $>0.5 \%$ dry weight of the needles) were detected in Pinus jefferyi Grev. and Balf.(Jeffrey pine), P. contorta Dougl. (lodgepole pine), Juniperus scopulorum Sarg. (Rocky Mountain juniper) and J. communis L. (common juniper) and from Cupressus macrocarpa Hartw. (Monterey cypress) from New Zealand and Australia. Abortions were induced when lodgepole pine and common juniper containing $0.7 \%$ and $2.5 \%$ ICA, respectively, were experimentally fed to pregnant cows, inducing abortions in 9 and 3.5 days, respectively (Gardner et al. 1998). This research confirmed field reports of lodgepole pine needle abortion in British Columbia, Canada (France, B., personal communication, 1997). Monterey cypress is known to cause abortions in cattle in New Zealand and Southern Australia and contained ICA levels of $0.89 \%$ to $1.24 \%$. The level of ICA in ponderosa pine needles is generally in the range of $0.5 \%$ and $1.7 \%$ (Gardner et al. 1994, Gardner and James 1999).

Occasional toxicoses from pine needles have been reported in field cases but are rare and have only occurred in pregnant cattle. No toxicity other than abortion in cattle has been demonstrated from ICA or ICA derivatives. However, the abietanetype resin acids in ponderosa pine needles (concentrated in new growth pine tips) were shown to be toxic but not abortifacient at high doses when administered orally to cattle, goats, and hamsters. Pathological evaluations of intoxicated animals included nephrosis, edema of the central nervous system, myonecrosis, and during cold weather, with increased snow depth, and when other forage is reduced or unavailable (Pfister and Adams 1993). Cattle are easily averted to green PN using an emetic (lithium chloride) paired with PN consumption, but aversions extinguish if cattle ingest dry needles intermingled with dormant grasses. Further research is underway to determine if cows can be successfully averted from green and dry needles simultaneously.

\section{Recommendations and Prevention}

Currently, recommendations to remove pregnant cattle in the last trimester of pregnancy from ponderosa pine-infested pastures or fencing around pine trees are the only preventive measures to ensure no losses from grazing pine needles.

When calves are born premature, some things can be done to improve the chances of calf and cow survival. Calves over 255 days gestation are likely to survive if given colostrum and kept warm and dry. The earlier the calves are born the less likely they are to survive. Cows will have retained fetal membranes and agalactia. Cows will come to their milk in a few days if the calf is encouraged to nurse, however the calf should be supplemented until that time. Generally, the placenta will be expelled in 10 to 15 days post partum if untreated. Oxytocin injection will aid in milk let down and also facilitate loss of the retained placenta. Cows should be monitored daily and if temperature is elevated appropriate antibiotic therapy should be administered. The local veterinarian should be consulted for appropriate treatment of the retained placenta. 


\section{Conclusion}

In this brief review we have discussed the effects of 3 classes of poisonous plants and their toxins that affect reproductive performance in livestock. While the effects described vary depending on the plant species or livestock species involved, the fact remains that natural toxins from poisonous plants have powerful and often detrimental effects on biological systems and especially reproductive function. These effects on reproduction may be subtle, like those described for locoweeds, before overt toxicosis becomes evident; they may be obvious and dramatic, as described in pine needle abortion in cattle; or the observed effects may be delayed yet dramatic as is the case when offspring are born with severe skeletal defects or cleft palate many months after the poisonous plant was ingested. These effects can be significant and cause large economic losses to livestock producers. Poisonous plant research provides new information and tools to better manage livestock grazing systems thus reducing losses and enhancing product quality. Additional spin-off benefits from research on poisonous plants include the development of animal models for human disease, new techniques and technologies such as antibody-based diagnostic tools (ELISA's) and treatments (vaccines), the discovery of novel compounds and improved management strategies that will enhance animal and human health.

\section{Literature Cited}

Binns, W. and L.F. James. 1961. A congenital deformity in calves, similar to "crooked calf disease," has been experimentally produced by feeding heifers lupine and lead. Proc. Western Sec. Amer. Soc. Anim. Prod. 12, LXVI, 1-3.

Carey, D.B. and M. Wink. 1994. Elevational variation of quinolizidine alkaloid contents in a lupine (Lupinus argenteus) of the Rocky Mountains. J. Chem. Ecol. 20:849-857.

Chesnut, V.K. and E.V. Wilcox. 1901. The stock-poisoning plants of Montana: A preliminary report. U.S. Dept. of Agr. Bull. No. 26. pp. 100-110. Washington D.C.

Davis, A.M. and D.M. Stout. 1986. Anagyrine in western American lupines. J. Range Manage. 39:29-30.

Gardner, D.R. and L.F. James. 1999. Pine needle abortion in cattle: Analysis of isocupressic acid in North American Gymnosperms. Phytochem. Anal. 10:1-5.
Gardner, D.R. and K.E. Panter. 1993. Comparison of blood plasma alkaloid levels in cattle, sheep and goats fed Lupinus caudatus. J. Nat.. Toxins 2:1-11.

Gardner, D.R., K.E. Panter and L.F. James. 1999. Pine needle abortion in cattle: Metabolism of isocupressic acid. J. Agr. Food Chem. 47:2891-2897.

Gardner, D.R., K.E. Panter, L.F. James and B.L. Stegelmeier. 1998. Abortifacient effects of lodgepole pine (Pinus contorta) and common juniper (Juniperus communis) on cattle. Vet. Human Toxicol. 40:260-263.

Gardner, D.R., R.J. Molyneux, L.F. James, K.E. Panter and B.L. Stegelmeier. 1994. Ponderosa pine needle-induced abortion in beef cattle: Identification of isocupressic acid as the principal active compound. J. Agr. Food Chem. 42:756-761.

Gardner, D.R., K.E. Panter, R.J. Molyneux, L.F. James and B.L. Stegelmeier. 1996. Abortifacient activity in beef cattle of acetyland succinyl- isocupressic acid from ponderosa pine. J. Agr. Food. Chem. 44:3257-3261.

Gardner, D.R., K.E. Panter, R.J. Molyneux, L.F. James, B.L. Stegelmeier and J.A. Pfister. 1997. Isocupressic acid and related diterpene acids from Pinus ponderosa as abortifacient compounds in cattle. J. Nat. Toxins 6:1-10.

James, L.F. and W.J. Hartley. 1977. Effects of milk from animals fed locoweed in kittens, calves, and lambs. Amer. J. Vet. Res. 38:1263-1265.

James, L.F., K.E. Panter, H.P. Broquist and W.J. Hartley. 1991. Swainsonine-induced high mountain disease in calves. Vet. Human Toxicol. 33:217-219.

James, L.F., R.J. Molyneux, K.E. Panter, D.R. Gardner and B.L. Stegelmeier. 1994. Effect of feeding Ponderosa pine needle extracts and their residues to pregnant cattle. Cornell Vet. 84:33-39.

James, L.F., R.E. Short, K.E. Panter, R.J. Molyneux, L.D. Stuart and R.A. Bellows. 1989. Pine needle abortion in cattle: A review and report of 1973-1984 research. Cornell Vet. 79:39-52.

Keeler, R.F. 1973. Lupine alkaloids from teratogenic and nonteratogenic lupins. II. Identification of the major alkaloids by tandem gas chromatography-mass spectrometry in plants producing crooked calf disease. Teratology 7:31-35.

Keeler, R.F. 1976. Lupin alkaloids from teratogenic and nonteratogenic lupins. III. Identification of anagyrine as the probable teratogen by feeding trials. J. Toxicol. Environ. Health 1:887-889.

Keeler, R.F. and L.D. Balls. 1978. Teratogenic effects in cattle of Conium maculatum and Conium alkaloids and analogs. Clin. Toxicol. 12:49-64.

Keeler, R.F. and M.W. Crowe. 1985. Anabasine, a teratogen from the Nicotiana genus, pp. 324-333. In: A.A. Seawright, M.P. Hegarty, L.F. James and R.F. Keeler (eds.), Plant Toxicology, Queensland Poisonous Plant Committee, Yeerongpilly.
Keeler, R.F. and K.E. Panter. 1989. Piperidine alkaloid composition and relation to crooked calf disease-inducing potential of Lupinus formosus. Teratology 40:423-432.

Keeler, R.F., L.F. James, J.L. Shupe and K.R. Van Kampen. 1977. Lupine-induced crooked calf disease and a management method to reduce incidence. J. Range Manage. 30:97-102.

Kinghorn, A.D. and M.F. Balandrin. 1984. pp. 105-148. In: S.W. Pelletier (ed). Alkaloids: Chemical and Biological Perspectives, John Wiley and Sons, N.Y.

Knight, A.P. and G. Greathouse. 1996. Locoweed in northern Colorado: Its effects on beef calves, p. 30. In: Locoweed and Broom Snakeweed Research Update. Agr. Exp. Sta., Coop. Exten. Service, College of Agr. and Home Econ., New Mexico State University.

Ortiz, A.R., D.M. Hallford, M.L. Galyean, F.A. Schneider and R.T. Kridli. 1997. Effects of locoweed (Oxytropis sericea) on growth, reproduction, and serum hormone profiles in young rams. J. Anim. Sci. 75:3229-3234.

Palotay, J.L. 1959. "Crooked calves". Western Vet. 6:16-20.

Panter, K.E. and R.F. Keeler. 1992. Induction of cleft palate in goats by Nicotiana glauca during a narrow gestational period and the relation to reduction in fetal movement. $J$. Nat. Toxins 1:25-32.

Panter, K.E., D.R. Gardner and R.J. Molyneux. 1994. Comparison of toxic and teratogenic effects of Lupinus formosus, $L$. arbustus and $L$. caudatus in goats. J. Nat. Toxins 3:83-93.

Panter, K.E., D.R. Gardner and R.J. Molyneux. 1998. Teratogenic and fetotoxic effects of two piperidine alkaloid-containing lupines ( $L$. formosus and L. arbustus) in cows. J. Nat. Toxins 7:131-140.

Panter, K.E., L.F. James and D.R. Gardner. 1999a. Lupines, poison-hemlock and Nicotiana spp: Toxicity and teratogenicity in livestock. J. Nat. Toxins 8:117-134.

Panter, K.E., L.F. James and W.J. Hartley. 1989. Transient testicular degeneration in rams fed locoweed (Astragalus lentiginosus). Vet. Human Toxicol. 31:42-46.

Panter, K.E., T.L. Wierenga and T.D. Bunch. 1991. Ultrasonographic studies on the fetotoxic effects of poisonous plants on livestock, pp. 589-610. In: R.F. Keeler and A.T. Tu, (eds.) Handbook of Natural Toxins: Volume 6, Toxicology of plant and fungal compounds. Marcel Dekker, Inc, N.Y.

Panter, K.E., T.D. Bunch, L.F. James and D.V. Sisson. 1987. Ultrasonographic imaging to monitor fetal and placental developments in ewes fed locoweed (Astragalus lentiginosus). Amer. J. Vet. Res. 48:686-690.

Panter, K.E., H.F. Mayland, D.R. Gardner and G. Shewmaker. 2001. Death losses in beef cattle after grazing Lupinus argenteus (silvery lupine). Vet. Human Toxicol. 43(5):279-282. 
Panter, K.E., T.D. Bunch, R.F. Keeler, D.V. Sisson and R.J. Callan. 1990. Multiple congenital contractures (MCC) and cleft palate induced in goats by ingestion of piperidine alkaloid-containing plants: Reduction in fetal movement as the probable cause. Clin. Toxicol. 28:69-83.

Panter, K.E., D.R. Gardner, L.F. James, B.L. Stegelmeier and R.J. Molyneux. 2000. Natural toxins from poisonous plant affecting reproductive function in livestock, pp.154-172. In: A.T. Tu and W. Gaffield (eds.), Natural and Selected Synthetic Toxins: Biological Implications. ACS Symp. Series 745. Amer. Chem. Soc., Washington, D.C.

Panter, K.E., L.F. James, B.L. Stegelmeier, M.H. Ralphs and J.A. Pfister. 1999b. Locoweeds: Effects on reproduction in livestock. J. Nat. Toxins 8:53-62.

Panter, K.E., M.H. Ralphs, L.F. James, B.L. Stegelmeier and R.J. Molyneux. 1999c. Effects of locoweed (Oxytropis sericea) on reproduction in cows with a history of locoweed consumption. Vet. Human Toxicol. 41:282-286.

Panter, K.E., D.R. Gardner, C.C. Gay, L.F. James, R. Mills, J.M. Gay and T.J. Baldwin. 1997. Observations of Lupinus sulphureus-induced "crooked calf disease". J. Range Manage. 50:587-592.

Pfister, J.A. and D.C. Adams. 1993. Factors influencing consumption of ponderosa pine needles by grazing cattle during winter. J. Range Manage. 46:394-398.
Pfister, J.A., J.B. Astorga, K.E. Panter and R.J. Molyneux. 1993. Maternal locoweed exposure in utero and as a neonate does not disrupt taste aversion learning in lambs. Appl. Anim. Behav. Sci. 36:159-167.

Ralphs, M.H., T.D. Whitson and D.N. Ueckert. 1991. Herbicide control of poisonous plants. Rangelands 13:73-77.

Ralphs, M.H., D. Graham, L.F. James and K.E. Panter. 1994. Locoweed effects on a calf crop. Rangelands 16:35-37.

Shupe, J.L., L.F. James and W. Binns. 1967b. Observations on crooked calf disease. J. Amer. Vet. Med. Assoc. 151:191-197.

Shupe, J.L., W. Binns L.F. James and R.F. Keeler. 1967a. Lupine, a cause of crooked calf disease. J. Amer. Vet. Med. Assoc. 151:198-203.

Shupe, J.L., W. Binns, L.F. James and R.F. Keeler. 1968b. A congenital deformity in calves induced by the maternal consumption of lupin. Aust. J. Agr. Res. 19:335-340.

Shupe, J.L., L.F. James, W. Binns and R.F. Keeler. 1968a. Cleft palate in cattle. The Cleft Palate J. 1:346-354.

Stegelmeier, B.L., L.F. James, K.E. Panter and R.J. Molyneux. 1995b. Serum swainsonine concentration and $\alpha$-mannosidase activity in cattle and sheep ingesting Oxytropis sericea and Astragalus lentiginosus (locoweeds). Amer. J. Vet. Res. 56:149-154.

Stegelmeier, B.L., R.J. Molyneux, A.D. Elbein and L.F. James. 1995a. The comparative pathology of locoweed, swainsonine, and castanospermine in rats. Vet. Pathol. 32:289-298.
Stegelmeier, B.L., D.R. Gardner, L.F. James, K.E. Panter and R.J. Molyneux. 1996. The toxic and abortifacient effects of Ponderosa pine. Vet. Pathol. 33:22-28.

Stegelmeier, B.L., L.F. James, K.E. Panter, M.H. Ralphs, D.R. Gardner, R.J. Molyneux and J.A. Pfister. 1999. The pathogenesis and toxicokinetics of locoweed (Astragalus and Oxytropis spp.). J. Nat. Toxins 8:35-45.

Van Kampen, K.R. and L.F. James. 1970. Pathology of locoweed (Astragalus lentiginosus) poisoning in sheep, Sequential development of cytoplasmic vacuolation in tissues. Pathol. Vet. 7:503-508.

Wagnon, K.A. 1960. Lupine poisoning as a possible factor in congenital deformities in cattle. J. Range Manage. 13:89-91.

Wang, S., G.R. Holyoak, K.E. Panter, G. Liu, R.C. Evans and T.D. Bunch. 1998. Resazurin reduction assay for ram sperm metabolic activity measured by spectrophotometry. Proc. Soc. Exp. Biol. Med 217:197-202.

Wang, S., K.E. Panter, G.R. Holyoak, R.J. Molyneux, G. Lin, R.C. Evans and T.D. Bunch. 1999. Development and viability of bovine preplacentation embryos treated with swainsonine in vitro. Animal Reprod. Sci. 56:19-29.

Wink, M. and D.B. Carey. 1994. Variability of quinolizidine alkaloid profiles of Lupinus argenteus (Fabaceae) from North America. Biochem. Syst. Ecol. 22:663-669.

Wink, M., C. Meibner and L. Witte. 1995. Patterns of quinolizidine alkaloids in 56 species of the genus Lupinus. Phytochemistry 38:139-153. 